DOI: https://doi.org/10.24127/ajpm.v9i3.2795

\title{
ANALISIS KESALAHAN SISWA MATERI BILANGAN PECAHAN BERDASARKAN TEORI NEWMAN
}

\author{
Budi Murtiyasa $^{1}$, Vivin Wulandari ${ }^{2}$ \\ ${ }^{1,2}$ Pendidikan Matematika, Universitas Muhammadiyah Surakarta, Indonesia \\ E-mail: $\quad \frac{\text { budi.murtiyasa@ums.ac.id }}{\text { vivindew@gmail.com }}{ }^{2)}$
}

Received 04 May 2020; Received in revised form 10 September 2020; Accepted 23 September 2020

\begin{abstract}
Abstrak
Penelitian ini bertujuan untuk mendeskripsikan kesalahan dan mengetahui penyebab kesalahan siswa dalam menyelesaikan soal cerita pada materi bilangan pecahan berdasarkan teori Newman. Jenis penelitian ini adalah deskriptif kualitatif. Subjek penelitian ini adalah 31 siswa kelas VII A SMP Muhammadiyah 2 Surakarta. Teknik pengumpulan data meliputi tes, wawancara, dan dokumentasi. Teknik analisis data yang dalam penelitian ini meliputi reduksi data, penyajian data, dan penarikan kesimpulan. Keabsahan data menggunakan triangulasi teknik. Hasil penelitian dapat disimpulkan bahwa (1) tidak ada siswa yang melakukan kesalahan membaca, (2) kesalahan memahami, penyebab siswa melakukan kesalahan dikarenakan siswa kurang memahami soal, (3) kesalahan transformasi, penyebab siswa melakukan kesalahan dikarenakan siswa kurang memahami soal sehingga siswa tidak dapat menentukan operasi yang digunakan untuk menyelesaikan soal dan siswa tidak tahu rumus atau operasi yang digunakan, (4) kesalahan keterampilan proses, penyebab siswa melakukan kesalahan disebabkan karena siswa lupa cara mengerjakan soal, kesalahan dalam menentukan rumus dan tidak teliti dalam melakukan perhitungan, (5) kesalahan penulisan jawaban, penyebab terjadinya kesalahan ini karena siswa tidak terbiasa menuliskan jawaban akhir (kesimpulan), dan adanya kesalahan pada proses perhitungan.
\end{abstract}

Kata kunci: Analisis kesalahan; bilangan pecahan; teori newman.

\begin{abstract}
The purpose of this study were to describe and find out the causes of students' error in solving story problem on fractions based on Newman's theory. This research used descriptive qualitative and the subjects were 31 students from class VII A in the Muhammadiyah 2 Junior High School of Surakarta. The data collection techniques consisted of tests, interviews, and documentation. The data analysis techniques in this study used data reduction, data presentation, and drawing conclusions. Meanwhile, the data validity used triangulation techniques. Based on the results of this study, it can be concluded that (1) there are no students who make reading errors, (2) comprehension errors, the cause of this errors is because students do not understand the purpose of the problem, (3) transformation errors, the cause of this errors is because students do not understand the problems thus cannot determine the operation used to solve the problem and they do not know the formula or operation used, (4) process skills errors, the cause of this errors is because students forget how to work on problems, errors in determining formulas and not careful in doing calculations, (5) encoding errors, the cause of this error is because students are not accustomed to writing the final answer (conclusion) and there are errors in the calculation process.
\end{abstract}

Keywords: Error analysis; fraction; newman's theory.

This is an open access article under the Creative Commons Attribution 4.0 International License

\section{PENDAHULUAN}

Dalam dunia kependidikan diperlukan usaha untuk mengadakan dan meningkatkan penguasaan pengetahuan. Penguasaan pengetahuan dalam pendidikan diharapkan dapat mengikuti perkembangan zaman. Pendidikan merupakan upaya menumbuhkan karakter dan pemikiran demi kehidupan yang selaras dengan 
dunia (Hasibuan, Saragih, \& Amry, 2019). Berbagai upaya dilakukan guna menciptakan generasi yang berkarakter dan dapat bersaing satu sama lain. Peranginangin, Saragih, \& Siagian (2019) memberikan pandangannya bahwa melalui pendidikan yang berkarakter diharapkan mampu memberikan persaingan tersendiri di bidang pendidikan.

Matematika merupakan mata pelajaran yang wajib diterima oleh setiap kalangan pada tiap tingkat pendidikan. Matematika ialah pengetahuan yang dibutuhkan seseorang untuk belajar dari sederhana ke tingkat yang lebih tinggi (Zakaria, 2010). Maka dapat dikatakan bahwa matematika merupakan suatu pengetahuan dasar bagi setiap orang.

Pembelajaran

matematika bertujuan untuk mengembangkan pengetahuan siswa dalam mengaplikasikan matematika itu sendiri di kehidupan nyata (Jha, 2012). Dengan demikian pembelajaran matematika tidak sekedar diperoleh siswa di kelas. Pada kenyatannya, ketika siswa memperoleh pembelajaran matematika di kelas masih ada anggapan bahwa matematika itu sulit. Fitrah (2017) mengungkapkan bahwa siswa terbiasa membahasakan matematika itu rumit, sulit, dan susah. Anggapan tersebut didukung oleh penelitian Wijaya, dkk. (2019) yang menjelaskan banyak siswa diberbagai tingkat pendidikan mengalami kesulitan dalam matematika. Mengacu pada pada Snapshot of Performance in Reading, Mathematics, and Science (OECD, 2019) menunjukkan bahwa skor PISA 2018 Indonesia dalam bidang matematika usia 15 tahun adalah 379 dengan rentang 0-1000 dimana 0 sebagai nilai terendah. Dari hasil tersebut, menggambarkan bahwa Indonesia jauh dibawah rerata internasional yaitu 489 .
Murtiyasa \& Perwita (2020) mengatakan bahwa hasil studi PISA yang masih dibawah rerata disebabkan karena siswa belum terlatih dalam menyelesaikan masalah-masalah PISA. Hal ini membuktikan bahwa kesulitan siswa dalam matematika memang benar adanya. Murtiyasa, Rejeki, \& Ishartono (2020) mengatakan kesulitan siswa dijumpai pada tahapan memahami dan mentransformasikan. Selain itu, Joseph (2011) mengungkapkan kesulitan siswa, diantaranya: (1) rendahnya kemampuan memahami masalah, (2) pengetahuan strategi yang masih kurang, (3) ketidakmampuan siswa dalam menerjemahkan masalah, (4) ketidakmampuan menggunakan matematika dengan tepat.

Berdasarkan hasil wawancara kepada salah seorang guru mata pelajaran matematika di SMP Muhammadiyah 2 Surakarta didapatkan informasi bahwa siswa kesulitan menyelesaikan masalah-masalah matematika yang berbentuk soal cerita. Soal berbentuk cerita itu sendiri ialah bentuk soal matematika yang merujuk pada masalah kehidupan sehari-hari yang disajikan dalam kalimat (Awofala, Balogun, \& Olagunju, 2011). Namun hal terebut berbanding terbalik dengan fakta bahwa siswa kesulitan dalam memahami soal cerita sehingga cenderung menerapkan rumus-rumus yang ada (Aisyah, Hariyani, \& Dinullah, 2019). Alasan lain diungkapkan oleh Wulandari, Zubaidah, \& Ijuddin (2014), diantaranya: (1) siswa sulit memahami permasalahan, (2) kesulitan dalam mentransformasikan permasalahan, (3) keterampilan berhitung yang masih kurang mengakibatkan siswa kesulitan menyelesaikan soal cerita. Selain itu, sebesar $68,18 \%$ siswa sulit memahami masalah yang disajikan, ketidakmampuan siswa menyelesaikan 
masalah, siswa tidak dapat memeriksa kembali hasil yang telah diperoleh (Mursalin, Fauzi, \& Israwati, 2017)

Bilangan pecahan adalah suatu materi pada mata pelajaran matematika yang dianggap sulit oleh siswa. Sutiarso (2019) dalam penelitiannya mengatakan jika siswa SMP kesulitan menyelesaikan soal-soal pecahan. Berdasarkan penelitian yang dilakukan oleh Ramlah, Bennu, \& Paloloang (2016) kurangnya pemahaman konsep pecahan menyebabkan siswa sulit menyelesaikan soal-soal pecahan. Aminah \& Kurniawati (2018) menjelaskan siswa kesulitan dalam memahami konsep dan soal pecahan (menyamakan penyebut) sehingga salah bahkan tidak menuliskan hasil akhir yang diminta, kesulitan menentukan operasi yang digunakan. Hal serupa diungkapkan oleh Zalima, dkk. (2020) bahwa siswa kesulitan menyelesaikan operasi hitung bilangan pecahan campuran.

Mengacu pada hasil wawancara menunjukkan bahwa siswa SMP Muhammadiyah 2 Surakarta kesulitan menyelesaikan soal cerita pada materi bilangan pecahan. Hal ini dibuktikan ketika guru mata pelajaran mengadakan ulangan harian materi bilangan pecahan berupa soal cerita, didapati banyak siswa memperoleh nilai dibawah KKM. Nilai ulangan yang masih dibawah KKM menandakan adanya kesalahan siswa SMP Muhammadiyah 2 Surakarta dalam mengerjakan soal cerita materi bilangan pecahan. Maelasari \& Jupri (2017) menyebutkan kesalahan siswa pada operasi pembagian bilangan pecahan, ialah: (1) kesalahan dalam membalik antara pembagian pecahan dengan bilangan bulat, (2) anggapan bahwa menyamakan penyebut dapat digunakan untuk menyelesaikan operasi hitung pecahan yang berbeda, penyelesaian operasi hitung pembagian bilangan pecahan dan bilangan bulat dapat dibagi langsung, dan (4) kesalahan dalam mengubah bentuk pecahan yaitu dengan menyederhanakan pembilang dan penyebut. Kesalahan siswa lainnya dalam menyelesaikan soal pecahan yaitu kesalahan pada konsep, prinsip, dan procedural (Badaruddin, Kadir, \& Anggo, 2016). Oleh sebab itu, untuk meminimalisir kesalahankesalahan tersebut perlulah ditangani melalui analisis kesalahan.

Untuk menyelesaikan suatu permasalahan matematika harus melalui beberapa tahapan. Newman (dalam White, 2010) tahapan tersebut, yaitu tahap membaca (reading), memahami (comprehension), transformasi (transformation), keterampilan proses (process skill), dan penulisan jawaban (encoding). Analisis kesalahan teori Newman digunakan untuk membantu mengetahui kesalahan siswa. Oleh karena itu, teori Newman dapat dijadikan acuan dalam menganalisis kesalahan siswa dan mengetahui penyebabnya. Dari uraian yang telah diberikan, tujuan penelitian ini yaitu untuk menganalisis kesalahan dan mengetahui penyebab kesalahan siswa dalam menyelesaikan soal cerita materi bilangan pecahan berdasarkan teori Newman pada kelas VII A SMP Muhammadiyah 2 Surakarta.

\section{METODE PENELITIAN}

Penelitian ini dilakukan di SMP Muhammadiyah 2 Surakarta. Jenis penelitian ini adalah kualitatif deskriptif karena tujuan dari penelitian ini adalah untuk memperoleh gambaran mengenai kesalahan siswa dalam menyelesaikan soal cerita pada materi bilangan pecahan. Subjek penelitian ini adalah kelas VII A dengan jumlah 31 siswa. Berdasarkan wawancara dengan guru 
DOI: https://doi.org/10.24127/ajpm.v9i3.2795

mata pelajaran matematika, kelas tersebut memiliki kemampuan sedang sehingga dapat digunakan sebagai subjek penelitian. Objek penelitian ini ialah kesalahan dan penyebab kesalahan siswa ketika menyelesaikan soal cerita materi bilangan pecahan.

Data dalam penelitian ini, yaitu (1) hasil pekerjaan dan (2) hasil kesalahan siswa. Hasil pekerjaan pada penelitian ini adalah jawaban siswa dalam menyelesaikan soal cerita materi bilangan pecahan. Hasil kesalahan siswa diperoleh dari hasil pekerjaan yang telah dianalisis. Analisis kesalahan pada penelitian ini yaitu analisis kesalahan teori Newman meliputi kesalahan membaca, kesalahan memahami, kesalahan transformasi, kesalahan keterampilan proses, dan kesalahan penulisan jawaban. Adapun indikator yang digunakan pada penelitian ini disajikan dalam Tabel 1.

Tabel 1. Indikator kesalahan teori Newman.

\section{Jenis Kesalahan Indikator Kesalahan}

Kesalahan Membaca Siswa dapat membaca tetapi tidak memahami arti masalah.

Kesalahan Memahami - Siswa tidak mengetahui/salah menuliskan apa yang diketahui dari soal.

- Siswa tidak mengetahui/salah menuliskan apa yang diketahui dari soal.

Kesalahan

Transformasi

Siswa tidak dapat memilih dan menentukan rumus, operasi,

Kesalahan

Keterampilan Proses dan prosedur matematika.

Siswa tidak dapat melakukan proses perhitungan

Kesalahan Penulisan Siswa tidak dapat menunjukkan jawaban yang benar.

Jawaban

(Suyitno \& Suyitno, 2015)

Pengujian keabsahan data pada penelitian ini dilakukan melalui triangulasi teknik, artinya mengumpulkan sumber data yang sama menggunakan teknik pengumpulan data yang berbeda. Teknik pengumpulan data pada penelitian ini, yaitu (1) tes, (2) wawancara, (3) dokumentasi. Instrumen utama dalam penelitian ini ialah pelaksana penelitian. Instrumen sekunder pada penelitian ini berupa tes soal cerita dengan materi bilangan pecahan sebanyak tiga buah soal yang sudah divalidasi oleh 2 orang validator yaitu satu guru mata pelajaran dan satu dosen pendidikan matematika. Tes pada penelitian ini digunakan untuk mengumpulkan data mengenai kesalahan siswa. Wawancara pada penelitian ini berfungsi untuk mengumpulkan informasi tambahan yaitu penyebab kesalahan siswa. Dokumentasi terdiri dari proses penelitian, foto hasil pekerjaan siswa, hasil wawancara.

Teknik analisis data yang digunakan dalam penelitian ini meliputi reduksi data, penyajian data, dan penarikan simpulan. Reduksi data yaitu menyederhanakan data yang diperoleh dari hasil pekerjaan siswa dan wawancara. Penyajian data yaitu menyajikan data yang didapatkan dari hasil kesalahan siswa dengan cara mendeskripsikan kesalahan siswa. Pada tahap terakhir dilakukan penarikan simpulan dari data-data yang diperoleh. 
DOI: https://doi.org/10.24127/ajpm.v9i3.2795

\section{HASIL DAN PEMBAHASAN}

Penelitian ini dilakukan dengan memberikan tes berupa soal cerita pada materi bilangan pecahan. Hasil pekerjaan siswa selanjutnya dilakukan analisis berdasarkan teori Newman. Berikut hasil pekerjaan siswa dalam menyelesaikan soal cerita pada materi bilangan pecahan berdasarkan teori Newman disajikan pada Tabel 2.

Tabel 2. Deskripsi kesalahan siswa.

\begin{tabular}{cccccc}
\hline \multirow{2}{*}{ Nomor Soal } & \multicolumn{5}{c}{ Jenis Kesalahan } \\
\cline { 2 - 6 } & $\mathbf{X}_{\mathbf{1}}$ & $\mathbf{X}_{\mathbf{2}}$ & $\mathbf{X}_{\mathbf{3}}$ & $\mathbf{X}_{\mathbf{4}}$ & $\mathbf{X}_{\mathbf{5}}$ \\
\hline 1 & 0 & 3 & 3 & 7 & 11 \\
2 & 0 & 3 & 7 & 11 & 17 \\
3 & 0 & 9 & 13 & 13 & 19 \\
Total & 0 & 15 & 23 & 31 & 47 \\
Persentase & $0 \%$ & $12,93 \%$ & $19,83 \%$ & $26,72 \%$ & $40,52 \%$ \\
\hline
\end{tabular}

Keterangan:

$\mathrm{X}_{1}=$ kesalahan membaca

$\mathrm{X}_{2}=$ kesalahan memahami

$\mathrm{X}_{3}=$ kesalahan transformasi

$\mathrm{X}_{4}=$ kesalahan keterampilan proses

$\mathrm{X}_{5}=$ kesalahan penulisan jawaban

Mengacu pada Tabel 2 diperoleh beberapa temuan kesalahan siswa dalam menyelesaikan soal tes, diantaranya:

1. Besar persentase siswa melakukan kesalahan membaca yaitu $0 \%$, artinya tidak ada kesalahan membaca.

2. Siswa melakukan kesalahan memahami sebesar $12,93 \%$.

3. Siswa melakukan kesalahan transformasi sebesar 19,83\%.
4. Siswa melakukan kesalahan keterampilan proses sebesar $26,72 \%$

5. Siswa melakukan kesalahan penulisan jawaban sebesar 40,52\%.

Pemilihan sampel dilakukan atas dasar subjek mana yang melakukan kesalahan. Berikut hasil analisis kesalahan siswa berdasarkan teori Newman.

1. Kesalahan Memahami

Berdasarkan Tabel 2 menunjukkan persentase siswa melakukan kesalahan memahami sebesar 12,93\% dengan 15 kesalahan. Berikut deskripsi kesalahan memahami siswa disajikan pada Tabel 3.

Tabel 3. Deskripsi kesalahan memahami siswa

\begin{tabular}{clcc}
\hline $\begin{array}{c}\text { Nomor } \\
\text { Soal }\end{array}$ & \multicolumn{1}{c}{ Deskripsi Kesalahan } & Frekuensi & Persentase \\
\hline 1 & $\begin{array}{l}\text { Tidak menuliskan apa yang diketahui dan apa yang } \\
\text { ditanyakan. }\end{array}$ & 3 & $9,68 \%$ \\
2 & Salah menuliskan apa yang diketahui & 2 & $6,45 \%$ \\
& Tidak menuliskan apa yang diketahui & 1 & $3,23 \%$ \\
3 & Salah menuliskan apa yang diketahui dan apa yang & 7 & $22,53 \%$ \\
& ditanyakan & 2 & $6,45 \%$ \\
\hline
\end{tabular}

Pada Tabel 3 diketahui bahwa kesalahan memahami terlihat saat siswa salah dan tidak dituliskannya informasi terkait apa yang diketahui dan ditanyakan pada soal. Kesalahan memahami terbanyak terdapat pada soal 
DOI: https://doi.org/10.24127/ajpm.v9i3.2795

nomor 3 dengan total 9 siswa. Hasil pekerjaan siswa yang melakukan

kesalahan memahami dapat dilihat pada Gambar 1 dan Gambar 2.

$$
\text { 1. } \frac{1}{5}+\frac{2}{-3}=\frac{3+10}{15}=\frac{13}{15}
$$

Gambar 1. Hasil pekerjaan subjek S20 soal nomor 1.

Gambar 1 memperlihatkan bahwa subjek melakukan kesalahan memahami yaitu tidak dituliskannya apa yang diketahui dan yang ditanyakan. Subjek hanya menuliskan $\frac{1}{5}+\frac{2}{3}=\frac{3+10}{15}=\frac{13}{15}$.

$$
\frac{2}{1} \text { di ketanui }=11 \frac{5}{6} \cdot \frac{7}{3} \cdot \frac{1}{2}
$$

Gambar 2. Hasil pekerjaan subjek S15 soal nomor 2.

Gambar 2 juga menunjukkan bahwa subjek melakukan kesalahan. Terlihat bahwa subjek melakukan kesalahan dalam memahami soal dimana tampak bahwa subjek tidak menuliskan informasi secara lengkap. Subjek hanya menulis $11 \frac{5}{6}, \frac{7}{3}, \frac{1}{2}$ tanpa keterangan apapun untuk menjelaskan bilangan pecahan tersebut. berdasarkan gambar 1 dan 2 diperoleh fakta bahwa kedua subjek melakukan kesalahan dalam memahami soal. Akan tetapi, kedua subjek memiliki letak kesalahan yang berbeda. Berdasarkan hasil wawancara terhadap kedua subjek, diketahui bahwa keduanya, baik subjek S20 maupun S15 sama-sama belum mampu memahami tentang permasalahan sebenarnya yang disajikan dalam soal.

\section{Kesalahan Transformasi}

Berdasarkan Tabel 2, besar persentase dari kesalahan siswa dalam memahami adalah sebesar 19,83\% dengan jumlah kesalahan sebanyak 23. Deskripsi dari kesalahan siswa dalam mentransformasikan permasalahan untuk semua nomor soal disajikan pada Tabel 4.

Tabel 4. Deskripsi kesalahan transformasi siswa

\begin{tabular}{clllcc}
\hline Nomor Soal & \multicolumn{3}{c}{ Deskripsi Kesalahan } & Frekuensi & Persentase \\
\hline 1 & $\begin{array}{l}\text { Salah memilih rumus, operasi, dan } \\
\text { algoritma. }\end{array}$ & 3 & $9,68 \%$ \\
2 & $\begin{array}{l}\text { Salah memilih rumus, operasi, dan } \\
\text { algoritma. }\end{array}$ & 7 & $22,58 \%$ \\
3 & $\begin{array}{l}\text { Salah memilih rumus, operasi, dan } \\
\text { algoritma. }\end{array}$ & 13 & $41,94 \%$ \\
\hline
\end{tabular}

Berdasarkan Tabel 4 menunjukkan banyak siswa melakukan kesalahan transformasi yaitu salah menentukan rumus, operasi, algoritma yang tepat. Kesalahan transformasi banyak terjadi pada soal nomor 3 dengan 13 siswa $(41,94 \%)$ dan soal nomor 2 dengan 7 siswa $(22,58 \%)$. Hasil pekerjaan siswa yang melakukan 
DOI: https://doi.org/10.24127/ajpm.v9i3.2795

kesalahan transformasi diilustrasikan pada Gambar 3 dan Gambar 4.

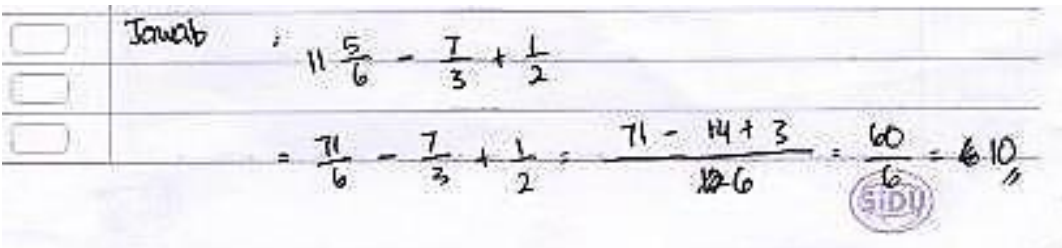

Gambar 3. Hasil pekerjaan subjek S14 soal nomor 2

Dari Gambar 3 ditunjukkan bahwa kesalahan transformasi terjadi dimana subjek salah dalam memilih operasi hitung. Menurut hasil pekerjaan tersebut, subjek menggunakan operasi hitung pengurangan dan penjumlahan yaitu $11 \frac{5}{6}-\frac{7}{3}+\frac{1}{2}$ untuk menentukan banyaknya kantong plastik. Seharusnya untuk menentukan banyaknya kantong plastik dicari dengan rumus $=11 \frac{5}{6}-\frac{7}{3} \div \frac{1}{2}$. Pada soal nomor 2 , subjek diminta untuk melibatkan operasi pengurangan dan pembagian, bukan operasi penjumlahan.

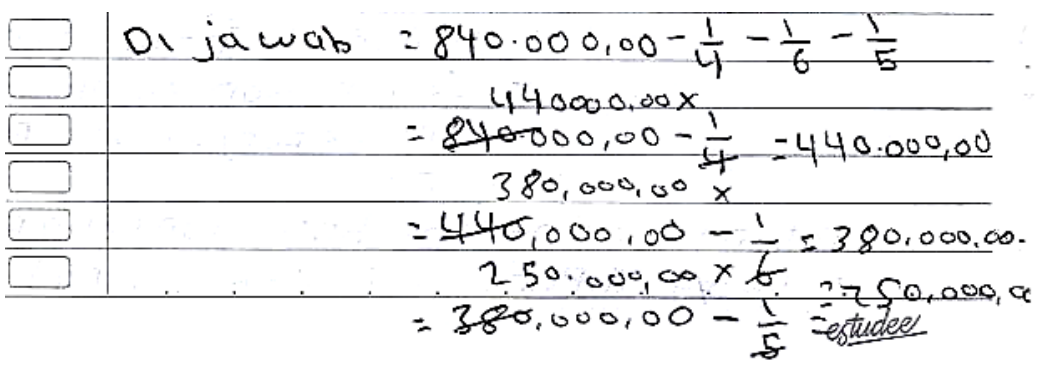

Gambar 4. Hasil pekerjaan subjek S16 soal nomor 3

Berdasarkan Gambar 4 menunjukkan kesalahan transformasi yang dilakukan subjek yaitu tidak dapat mengidentifikasi operasi dengan tepat. Dalam menyelesaikan permasalahan soal nomor 3 yaitu mencari besar uang yang ditabung pak Anwar dengan rumus $=840.000,00-\frac{1}{4}-\frac{1}{6}-\frac{1}{5}$.

Padahal rumus yang digunakan untuk menentukan besar bagian uang yang ditabung pak Anwar yaitu $=1-\left(\frac{1}{4}+\frac{1}{6}+\frac{1}{5}\right)$ kemudian mencari besar uang tersebut dengan mengalikan besar bagian uang yang ditabung dengan Rp 840.000,00. Selain itu, subjek dapat menggunakan alternatif lain, seperti mengalikan satu per satu bagian dengan $\mathrm{Rp} 840.000,00$ untuk mendapatkan besar uang tiap bagian. Kemudian mengurangkan $\mathrm{Rp}$ 840.000,00 dengan hasil penjumlahan dari ketiga bagian yang telah dicari terlebih dahulu nominalnya. Berdasarkan hasil wawancara terhadap subjek S14 dan S16 diperoleh informasi bahwa kedua subjek tidak mengetahui rumus apa yang digunakan. Ketidaktahuan mengenai rumus ini disebabkan karena kedua subjek kurang memahami masalah dalam soal.

3. Kesalahan Keterampilan Proses

Pada Tabel 2 diperlihatkan bahwa besar persentase kesalahan 
DOI: https://doi.org/10.24127/ajpm.v9i3.2795

keterampilan proses siswa sebesar deskripsi kesalahan keterampilan proses $26,72 \%$ dengan 31 kesalahan. Berikut siswa yang disajkan dalam Tabel 5 .

Tabel 5. Deskripsi kesalahan keterampilan proses siswa.

\begin{tabular}{clcc}
\hline Nomor Soal & \multicolumn{1}{c}{ Deskripsi Kesalahan } & Frekuensi & Persentase \\
\hline $\mathbf{1}$ & Salah dalam proses perhitungan. & 3 & $9,68 \%$ \\
& Salah memperoleh hasil perhitungan. & 4 & $12,90 \%$ \\
$\mathbf{2}$ & Salah dalam proses perhitungan. & 7 & $22,58 \%$ \\
& Salah melakukan operasi. & 4 & $12,90 \%$ \\
$\mathbf{3}$ & Salah dalam proses perhitungan. & 13 & $41,94 \%$ \\
\hline
\end{tabular}

Pada Tabel 5 kesalahan keterampilan proses siswa ditunjukkan dari siswa salah melakukan proses perhitungan, salah memperoleh hasil, dan salah dalam melakukan operasi. Kesalahan keterampilan proses banyak dijumpai pada soal nomor 3 dengan 13 siswa dan total 11 siswa pada soal nomor 2. Berikut kesalahan keterampilan proses siswa berdasarkan hasil pekerjaannya diilustrasikan pada Gambar 5 dan Gambar 6.

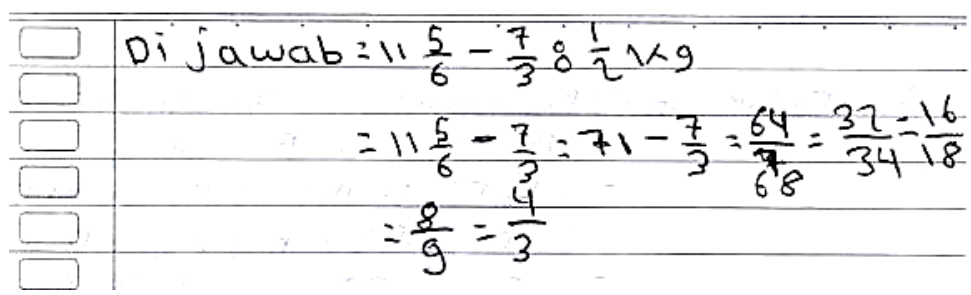

Gambar 5. Hasil pekerjaan subjek S16 soal nomor 2

Dari Gambar 5 memperlihatkan bahwa subjek salah dalam melakukan perhitungan. Kesalahan perhitungan dimana subjek mendahulukan operasi pengurangan daripada operasi pembagian yaitu pada $=11 \frac{5}{6}-\frac{7}{3}=71-$ $\frac{7}{3}=\frac{64}{68}=\frac{32}{34}=\frac{16}{18}=\frac{8}{9}=\frac{4}{3}$ Seharusnya, subjek melakukan operasi pembagian terlebih dulu kemudian operasi pengurangan yaitu $=11 \frac{5}{6}-\frac{7}{3} \div \frac{1}{2}=\frac{71}{6}-\left(\frac{7}{3} \div \frac{1}{2}\right)$.

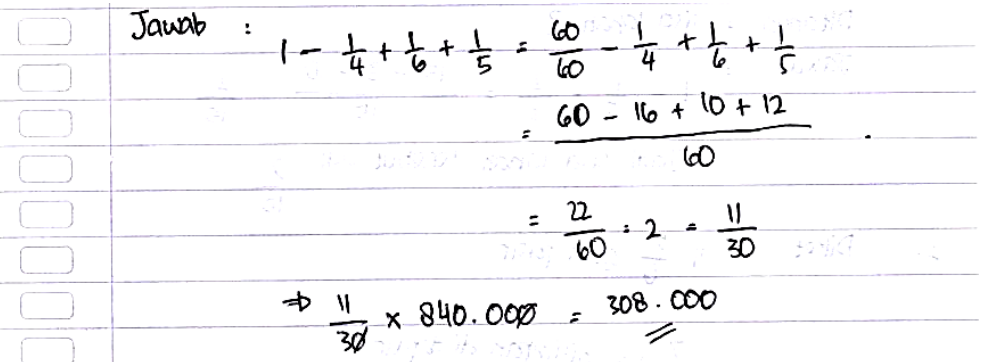

Gambar 6. Hasil pekerjaan subjek S14 soal nomor 3

Dari Gambar 6 memperlihatkan subjek melakukan kesalahan pada proses perhitungan yaitu subjek salah menghitung hasil pembagian dari
$60 \div 4=16$. Hasil pembagian yang benar dari $60 \div 4=15$. Dengan demikian, kesalahan proses perhitungan subjek 
DOI: https://doi.org/10.24127/ajpm.v9i3.2795

terjadi saat melakukan operasi pembagian.

Gambar 5 dan 6 menunjukkan kesalahan keterampilan proses dilakukan oleh kedua subjek. Berdasarkan hasil wawancara, kesalahan perhitungan subjek S16 disebabkan karena subjek lupa operasi apa yang harus didahulukaan antara pengurangan dan pembagian. selain itu, penyebab lain dikarenakan kurangnya ketelitian dari kedua subjek.

\section{Kesalahan Penulisan Jawaban}

Pada Tabel 2 besar persentase kesalahan penulisan jawaban siswa sebesar 40,52\%. Berikut deskripsi kesalahan penulisan jawaban siswa disajikan dalam Tabel 6.

Tabel 6. Deskripsi Kesalahan Penulisan Jawaban Siswa

\begin{tabular}{cccc}
\hline Nomor Soal & Deskripsi Kesalahan & Frekuensi & Persentase \\
\hline \multirow{2}{*}{2} & Salah menuliskan jawaban akhir & 7 & $22,58 \%$ \\
& Tidak menuliskan jawaban akhir & 4 & $12,90 \%$ \\
& Salah menuliskan jawaban akhir & 11 & $35,48 \%$ \\
\multirow{2}{*}{3} & Tidak menuliskan jawaban akhir & 6 & $19,35 \%$ \\
& Salah menuliskan jawaban akhir & 13 & $41,94 \%$ \\
& Tidak menuliskan jawaban akhir & 6 & $19,35 \%$ \\
\hline
\end{tabular}

Berdasarkan Tabel 6 diperoleh kesalahan penulisan jawaban terbanyak dilakukan sebanyak 19 siswa ketika mengerjakan soal ketiga, kemudian 17 siswa salah pada soal kedua, dan 11 siswa pada soal pertama. Kesalahan ini ditandai dengan siswa yang salah bahkan sampai tidak menuliskan jawaban akhir (kesimpulan) yang diminta. Berikut hasil pekerjaan siswa yang melakukan kesalahan penulisan jawaban diilustrasikan pada Gambar 7 dan Gambar 8.

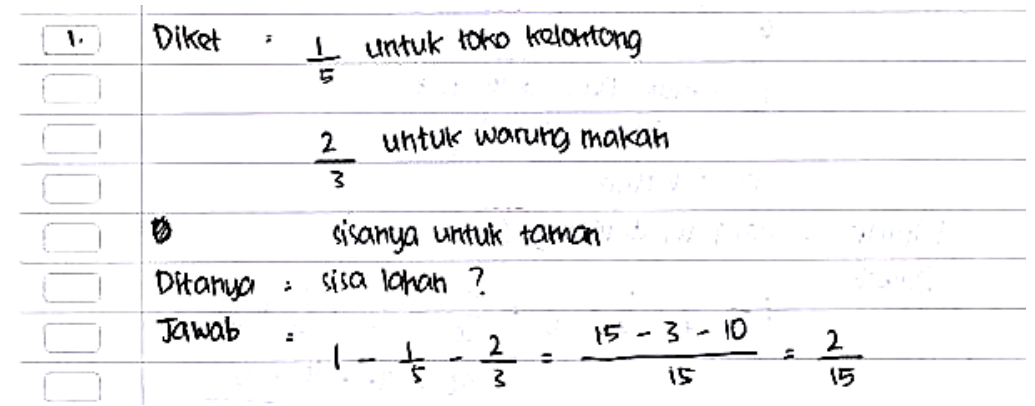

Gambar 7. Hasil pekerjaan subjek S14 soal nomor 1
Gambar 7 memperlihatkan letak kesalahan penulisan jawaban subjek yaitu tidak dituliskannya jawaban akhir yang diminta. Meskipun demikian pada tahap sebelum-sebelumnya subjek dapat menuliskan hingga menyelesaikan proses perhitungan secara tepat. 
DOI: https://doi.org/10.24127/ajpm.v9i3.2795

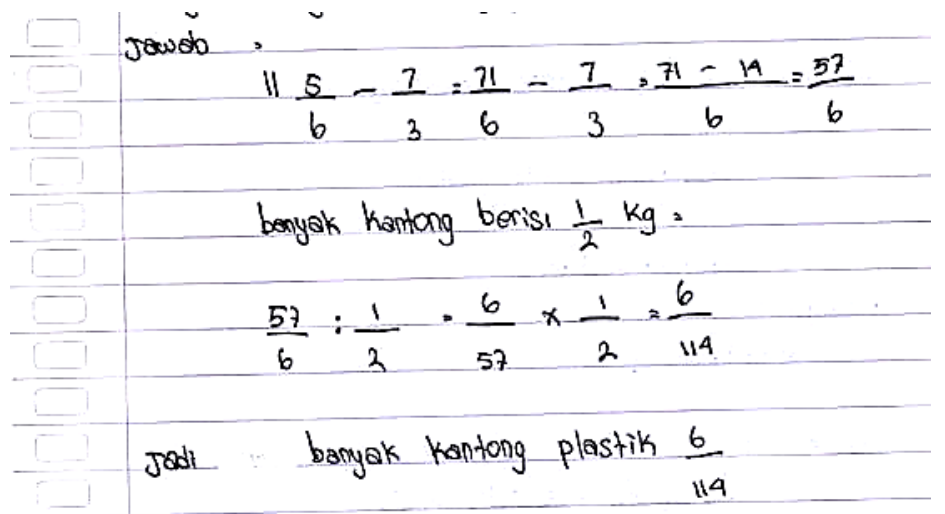

Gambar 8. Hasil pekerjaan subjek S31 soal nomor 2

Dari Gambar 8 terlihat bahwa subjek dapat menuliskan jawaban akhir. Namun, jawaban tersebut bukanlah jawaban akhir yang diminta. Maka dapat disimpulkan bahwa subjek salah dalam menuliskan jawaban akhir. Kesalahan tersebut disebabkan karena adanya kesalahan pada tahap sebelumnya yaitu tahap perhitungan. Kesalahan yang dimaksud yaitu pada proses pembagian dimana $\frac{57}{6} \div \frac{1}{2}=\frac{6}{57} \times$ $\frac{1}{2}=\frac{6}{114}$ seharusnya dikerjakan dengan $\frac{57}{6} \div \frac{1}{2}=\frac{57}{6} \times \frac{2}{1}=\frac{114}{6}=19$.

Dari Gambar 7 dan 8 kesalahan penulisan jawaban ditunjukkan dengan subjek salah dan tidak menuliskan jawaban akhir yang diminta. Berdasarkan hasil wawancara kepada subjek S14 diketahui bahwa penyebab subjek tidak menuliskan jawaban karena subjek beranggapan bahwa hasil perhitungan adalah jawaban akhir yang diminta. Oleh sebab itu, subjek terbiasa dengan tidak menuliskan jawaban akhir pada lembar kerjanya. Penyebab lain disebabkan oleh kesalahan perhitungan yang salah pada tahap sebelumnya.

Berdasarkan hasil pekerjaan dan hasil wawancara siswa yang telah dianalisis. Kesalahan dan penyebab kesalahan siswa pada penelitian ini yaitu:
1. Siswa melakukan kesalahan memahami masalah seperti tidak dituliskannya informasi mengenai apa yang diketahui dan yang ditanyakan, serta ketidaksesuai informasi yang dituliskan. Sesuai dengan penelitian yang dilakukan oleh Suyitno \& Suyitno (2015) kesalahan memahami terjadi apabila siswa salah menuliskan apa yang diketahui, apa yang ditanyakan, serta tidak dituliskannya informasi apapun. Sejalan dengan Jha (2012) kesalahan memahami dikarenakan pemahaman siswa yang tidak utuh terhadap soal sehingga tidak dituliskannya informasi terkait masalah pada soal. Mengacu pada hasil wawancara diketahui kesalahan memahami pada penelitian ini disebabkan siswa yang tidak paham terhadap soal yang diberikan. Serupa dengan hasil penelitian Oktaviana (2017) siswa yang tidak memahami maksud dari soal merupakan penyebab kesalahan memahami siswa. Kristianto, dkk. (2019) menambahkan siswa dapat membaca dengan benar tetapi tidak memahami masalah secara keseluruhan atau istilah dalam masalah.

2. Kesalahan transformasi dimana siswa tidak dapat mengidentifikasi operasi, algoritma ataupun rumus yang tepat untuk memecahkan masalah yang diberikan. Senada dengan hasil penelitian Abdullah, dkk. (2015) 
kesalahan transformasi yaitu siswa gagal menentukan operasi matematika. Dari hasil wawancara penyebab siswa salah dalam menuliskan rumus, operasi ataupun algoritma adalah ketidaktahuan siswa mengenai rumus yang digunakan. Sesuai dengan penelitian Junaedi, dkk. (2015) penyebab kesalahan ini dikarenakan siswa tidak tahu rumus dan algoritma. Penyebab lain terjadinya kesalahan transformasi dikarenakan siswa gagal memahami masalah. Sesuai hasil penelitian yang dilakukan oleh Suyitno \& Suyitno (2015) mengungkapkan kurangnya pemahaman soal, kesalahan konsep, dan kecerobohan menyebabkan kesalahan transformasi.

3. Kesalahan keterampilan proses siswa sering terjadi dimana siswa salah menjalankan operasi seperti kesalahan mendahulukan operasi hitung, salah memperoleh hasil perhitungan, dan salah melakukan perhitungan. Senada dengan hasil penelitian Abdullah, dkk. (2015) kesalahan perhitungan terjadi saat siswa gagal melakukan prosedur dengan benar. Hal serupa diungkapkan Junaedi, dkk. (2015) dalam penelitiannya bahwa kesalahan perhitungan ditunjukkan dengan ketidakmampuan siswa menggunakan algoritma secara urut dan benar. Menurut hasil wawancara diperoleh kesalahan perhitungan disebabkan siswa lupa operasi mana yang harus didahulukan. Selain itu, kurangnya ketelitian subjek dalam proses perhitungan. Sesuai hasil riset Rohmah \& Sutiarso (2018) siswa yang tidak berhati-hati dan tidak teliti dalam proses pengerjaan menjadi penyebab kesalahan perhitungan.

4. Kesalahan dalam menuliskan jawaban akhir (kesimpulan) merupakan kesalahan siswa yang kerap dilakukan. Hampir sebagian siswa melakukan kesalahan ini. Terbukti banyak siswa salah menuliskan dan tidak menuliskan jawaban akhirnya. Selaras dengan hasi hasil temuan pada penelitian Sari \& Valentino (2016) menyatakan kesalahan dalam menuliskan kesimpulan terjadi saat siswa menuliskan kesimpulan yang tidak sesuai. Kristianto, dkk. (2019) siswa memecahkan masalah tetapi tidak menuliskan solusi yang sesuai. Menurut hasil wawancara diketahui penyebab kesalahan dalam menuliskan jawaban akhir disebabkan adanya kesalahan menghitung yang dilakukan oleh siswa. Sesuai hasil penelitian Wahidah \& Ismail (2017) proses perhitungan yang salah menyebabkan kesalahan pada penulisan jawaban. Penyebab lain mengapa siswa tidak menuliskan jawaban disebabkan siswa terbiasa untuk menuliskan jawaban akhir (kesimpulan) pada lembar kerjanya. Selaras dengan hasil temuan Farida (2015) pada penelitiannya yang menyatakan jika siswa tidak terbiasa menuliskan kesimpulan dari suatu pertanyaan.

\section{KESIMPULAN DAN SARAN}

Berdasarkan hasil penelitian dan pembahasan dapat disimpulkan bahwa kesalahan siswa dalam menyelesaikan soal cerita pada materi bilangan pecahan, yaitu: pertama, kesalahan memahami, penyebab siswa melakukan kesalahan yaitu siswa tidak memahami maksud dari soal. Kedua, kesalahan transformasi, penyebab siswa melakukan kesalahan dikarenakan siswa kurang memahami soal sehingga tidak dapat menentukan operasi yang digunakan untuk menyelesaikan soal dan siswa tidak tahu rumus atau operasi yang digunakan. Ketiga, kesalahan keterampilan proses, penyebab siswa melakukan kesalahan ini disebabkan karena siswa lupa cara mengerjakan 
soal, kesalahan dalam menentukan rumus dan tidak teliti dalam melakukan proses perhitungan. Keempat, kesalahan penulisan jawaban, penyebab terjadinya kesalahan ini karena siswa tidak terbiasa dalam menuliskan jawaban akhir (kesimpulan) dan adanya kesalahan pada proses perhitungan.

Berdasarkan hasil penelitian maka disarankan kepada siswa hendaknya lebih banyak berlatih secara mandiri mengerjakan soal terutama soal cerita. Selain itu, sebelum mengerjakan soal sebaiknya siswa menuliskan terlebih dahulu informasi secara lengkap yang ada di soal. Dengan menuliskan informasi tersebut, siswa tidak hanya berlatih memahami masalah tetapi juga belajar menggunakan prosedur yang benar. Demikian halnya pada proses perhitungan siswa dapat melakukan hal serupa dengan dibantu guru dalam melakukan perhitungan.

\section{DAFTAR PUSTAKA}

Abdullah, A. H., Abidin, N. L. Z., \& Ali, M. (2015). Analysis of students' errors in solving Higher Order Thinking Skills (HOTS) problems for the topic of fraction. Asian Social Science, 11(21), 133-142. https://doi.org/10.5539/ass.v11n21p 133

Aisyah, F. N. K., Hariyani, S., \& Dinullah, R. N. I. (2019). Analisis Kesalahan Penyelesaian Soal Cerita berdasarkan Kriteria Watson. Jurnal Review Pembelajaran Matematika (Jrpm), 4(1), 11-22. https://doi.org/https://doi.org/10.156 42/jrpm.2019.4.1.11-22

Aminah, A., \& Ayu Kurniawati, K. R. (2018). Analisis Kesulitan Siswa dalam Menyelesaikan Soal Cerita Matematika Topik Pecahan Ditinjau dari Gender. JTAM | Jurnal Teori dan Aplikasi Matematika, 2(2), 118. https://doi.org/10.31764/jtam.v2i2.7 13
Awofala, A. O. A., Balogun, T. A., \& Olagunju, M. A. (2011). Effects of Three Modes of Personalization On Students' Achievement in Mathematics Word Problems in Nigeria. International Journal for Mathematics Teaching and Learning.

Badaruddin, Kadir, \& Anggo, M. (2016). Analisis Kesalahan Dalam Menyelesaikan Soal-Soal Operasi Hitung Pecahan Pada Siswa Kelas Vii Smp Negeri 10 Kendari. Jurnal Penelitian Pendidikan Matematika, 5(1), 99-113.

Farida, N. (2015). Analisis Kesalahan Siswa SMP Kelas VIII Dalam Menyelesaikan Masalah Soal Cerita Matematika. AKSIOMA: Jurnal Program Studi Pendidikan Matematika, 4(2), 42-52.

Fitrah, M. (2017). Pembelajaran Berbasis Masalah Untuk Meningkatkan Pemahaman Konsep Matematika Pada Materi Segiempat Siswa Smp. KALAMATIKA Jurnal Pendidikan Matematika, 2(1), 51. https://doi.org/10.22236/kalamatika. vol2no1.2017pp51-70

Hasibuan, A. M., Saragih, S., \& Amry, Z. (2018). Development of Learning Materials Based on Realistic Mathematics Education to Improve Problem Solving Ability and Student Learning Independence. International Electronic Journal of Mathematics Education, 14(1), 243252.

https://doi.org/10.29333/iejme/4000

Jha, S. K. (2012). Mathematics performance of primary school students in Assam (India): An analysis using Newman Procedure. International Journal of Computer Applications in in Engineering Sciences, II(I), 17-21. http://citeseerx.ist.psu.edu/viewdoc/ download?doi=10.1.1.303.2464\&rep $=$ rep $1 \&$ type $=$ pdf 
DOI: https://doi.org/10.24127/ajpm.v9i3.2795

Joseph, Y. K. K. (2011). An Exploratory Study of Primary Two Pupils' Approach to Solve Word Problems. Journal of Mathematics Education (C) Education for All, 4(1), 19-30.

Junaedi, I., Suyitno, A., Sugiharti, E., \& Eng, C. K. (2015). Disclosure Causes of Students Error in Resolving Discrete Mathematics Problems Based on NEA as A Means of Enhancing Creativity. International Journal of Education, 7(4), 31. https://doi.org/10.5296/ije.v7i4.8462

Kristianto, E., Mardiyana, \& Saputro, D. R. S. (2019). Analysis of Students' Error in Proving Convergent Sequence using Newman Error Analysis Procedure. Journal of Physics: Conference Series, 1180(1). https://doi.org/10.1088/17426596/1180/1/012001

Maelasari, E., \& Jupri, A. (2017). Analysis of Student Errors on Division of Fractions. Journal of Physics: Conference Series. https://doi.org/10.1088/17426596/812/1/012033

Mursalin, Fauzi, \& Israwati. (2017). Kemampuan Siswa Dalam Menyelesaikan Soal Matematika Dalam Bentuk Pemecahan Masalah Bagi Siswa Kelas V SD Negeri 1 Pagar Air Aceh Besar. Jurnal Ilmiah Pendidikan Guru Sekolah Dasar, 2(2), 38-44.

Murtiyasa, B., \& Perwita, W. R. G. (2020). Analysis of Mathematics Literation Ability of Students in Completing PISA-Oriented Mathematics Problems with Changes and Relationships Content. Universal Journal of Educational Research, 8(7), 3160-3172. https://doi.org/10.13189/ujer.2020.0 80745

Murtiyasa, B., Rejeki, S., \& Ishartono, N. (2020). Profile o f Students ' Error in Solving Mathematics Word Problems Based on PISA
Frameworks. Advances in Social Science, Education and Humanities Research, Volume 467 Proceedings of the SEMANTIK Conference of Mathematics Education (SEMANTIK 2019), 467(Semantik 2019), 135-137. https://doi.org/10.2991/assehr.k.200 827.131

OECD. (2019). PISA 2018 Results. Combined Executive Summaries. Journal of Chemical Information and Modeling, 53(9), 1689-1699. https://doi.org/10.1017/CBO978110 7415324.004

Oktaviana, D. (2018). Analisis Tipe Kesalahan Berdasarkan Teori Newman Dalam Menyelesaikan Soal Cerita Pada Mata Kuliah Matematika Diskrit. Edu Sains: Jurnal Pendidikan Sains \& Matematika, $5(2), \quad 22$. https://doi.org/10.23971/eds.v5i2.71 9

Peranginangin, S. A., Saragih, S., \& Siagian, P. (2019). Development of Learning Materials through PBL with Karo Culture Context to Improve Students' Problem Solving Ability and Self-Efficacy. International Electronic Journal of Mathematics Education, 14(2), 265274. https://doi.org/10.29333/iejme/5713

Ramlah, Bennu, S., \& Paloloang, B. (2020). Analisis Kesalahan Siswa Dalam Menyelesaikan Soal Penjumlahan dan Pengurangan Pecahan Di Kelas VII SMPN Model Terpadu Madani. Jurnal Ilmiah Pendidikan Matematika, 1(2), 182194.

http://ojs.uho.ac.id/index.php/JPM/a rticle/view/10022

Rohmah, M., \& Sutiarso, S. (2018). Analysis problem solving in mathematical using theory Newman. Eurasia Journal of Mathematics, Science and Technology Education, 14(2),

671-681. 
DOI: https://doi.org/10.24127/ajpm.v9i3.2795

https://doi.org/10.12973/ejmste/8063 0

Sari, Y. M., \& Valentino, E. (2017). An Analysis of Students Error In Solving PISA 2012 And Its Scaffolding. JRAMathEdu (Journal of Research and Advances in Mathematics Education), 1(2), 9098.

https://doi.org/10.23917/jramathedu. v1i2.3380

Sulistyorini, Y. (2017). Analisis Kesalahan Dan Scaffolding Dalam Penyelesaian Persamaan Diferensial. KALAMATIKA Jurnal Pendidikan Matematika, 2(1), 91. https://doi.org/10.22236/kalamatika. vol2no1.2017pp91-104

Sutiarso, S. (2019). Mengapa Sulit Menyelesaikan Soal Pecahan $2 / a+3 / b=2 / 3$ ? AKSIOMA: Jurnal Program Studi Pendidikan Matematika, $8(3), \quad 420$. https://doi.org/10.24127/ajpm.v8i3.2 349

Suyitno, A., \& Suyitno, H. (2015). Learning therapy for students in mathematics communication correctly based-on application of newman procedure (a case of indonesian student). International Journal of Education and Research, 3(1), 529-538.

Wahidah, Y. N., Inganah, S., \& Ismail, A. D. (2017). The Analysis of Mathematical Problems Using Newman Stages Reviewed From Emotional Intelligence. 1(2), 56-62.

Widodo, A. N. A., Sujadi, I., \& Mardiyana. (2017). Analisis Kesalahan Siswa Dalam Menyelesaikan Soal Kesebangunan Berdasarkan Prosedur Newman Ditinjau Dari Kemampuan Spasial. Journal of Mathematics and Mathematics Education, 7(1), 1320.
Wijaya, A., Retnawati, H., Setyaningrum, W., \& Aoyama, K. (2019). Diagnosing Students ' Learning Difficulties in the E Yes. 10(3), 357364.

Wulandari, N., Zubaidah, \& Ijuddin, R. (2014). Kemampuan Pemecahan Masalah Dalam Menyelesaikan Soal Cerita Sistem Persamaan Linear Dua Variabel Di SMP. Jurnal Pendidikan Dan Pembelajaran Khatulistiwa, 3(7), 1-10. http://jurnal.untan.ac.id/index.php/jp dpb/article/view/5549/6313

Zakaria, E., --, I., \& Maat, S. M. (2010). Analysis of Students' Error in Learning of Quadratic Equations. International Education Studies, 3(3), 105-110. https://doi.org/10.5539/ies.v3n3p105

Zalima, E. I., Njanji, F. P., Lasmiatik, L., Agustina, L., \& Dela, M. (2020). Analisis Kesulitan Siswa Dalam Menyelesaikan Soal Cerita Operasi Hitung Pada Bilangan Pecahan Campuran. Prismatika: Jurnal Pendidikan Dan Riset Matematika, 2(2), 46-54. https://doi.org/10.33503/prismatika. v2i2.658 